pro $\mathrm{cm}^{3}$. Der steilere Anstieg wird verständlich, wenn man annimmt, daß bei den Entladungen in clusterStrahlen die Gleichung für den Aufbau eines Plasmas in einem Gas gilt,

$$
\mathrm{d} n_{\mathrm{i}} / \mathrm{d} t=n_{0} n_{\mathrm{e}} \overline{\sigma v}-\alpha\left(n_{\mathrm{e}}, T_{\mathrm{e}}\right) n_{\mathrm{i}} n_{\mathrm{e}} .
$$

$(\overline{\sigma v}=$ Mittelwert des Produkts Ionisierungsquerschnitt $\sigma \times$ Elektronengeschwindigkeit $v$ bezüglich aller vorhandenen Geschwindigkeiten; $\alpha=$ Rekombinationskoeffizient; $n_{\mathrm{e}}=$ Elektronendichte $=$ Ionendichte $n_{\mathrm{i}}$ ).

Danach ist der erste, die Ionenerzeugung beschreibende Term der Neutronteilchendichte $n_{0}$ proportional.

Das Verhältnis der gemessenen Anstiegsraten und der Maxima ist jedoch kleiner als das der Neutralteilchendichten, was durch den stärker von $n_{\mathrm{i}}$ abhängenden zweiten, die Ionenvernichtung beschreibenden Term erklärlich ist.
Auffällig ist, daß die Ionendichte bei der größeren Neutralteilchendichte bereits vor Durchlaufen des Strommaximums wieder absinkt. Aus früheren Bildwandleraufnahmen ${ }^{6}$ ist aber bekannt, daß der aufgeheizte Plasmafaden mit einer radialen Geschwindigkeit von ca. $1,5 \cdot 10^{6} \mathrm{~cm} / \mathrm{sec}$ expandiert, was einer Vervierfachung des Volumens in 100 nsec entspricht. Es ist daher wahrscheinlich, daß sich der Dichteabbau durch thermische Expansion dem schnelleren Plasmaaufbau entsprechend früher bemerkbar macht.

Wir danken Herrn Prof. E. W. Becker für die Förderung der Arbeit und wertvolle Diskussionen und Frau J. VogelsGESANG für ihre Hilfe bei den Experimenten und bei der Auswertung der Meßergebnisse.

${ }^{6}$ R. Klingelhöfer, H. Röhl u. J. Wüst, Z. Naturforsch. 21 a, 1967 [1966].

\section{Cation Mobilities in Molten Binary and Ternary Nitrate Mixtures}

\author{
A. Lundén \\ Department of Physics, Chalmers University of Technology \\ Göteborg, Sweden \\ (Z. Naturforsch. 25 a, 1362-1364 [1970]; received 10 July 1970)
}

Some relative cation mobilities determined by the column method are reported. The results are compared with external ion mobilities reported by a number of authors who used the zone electrophoresis technique. In some cases the agreement is sufficient, in others the discrepancy is evident, but this can also occur when different measurements of external mobilities are compared with each other. Some sources of error are discussed.

The techniques used to determine electromigration mobilities in molten salt mixtures can be divided into two classes. In a review by ALBERTi and ALLULLI ${ }^{1}$ the first one was called "open-block method of zone electrophoresis". Here a zone of a tracer migrates along a strip of some porous medium, which is soaked with molten salt. Since the displacement along a strip is measured, the ion mobilities are measured relative to the support, and are thus "external mobilities". Techniques of this class have been used by a number of research groups, mainly in France, Italy and the Netherlands, and the results obtained prior to October 1967 have been summarized in ${ }^{1}$, where also a discussion of some experimental difficulties is found. The other class was originally developed by KLEMm for studying

Reprints request to Dr. A. Lundén, Department of Physics Chalmers University of Technology, S-40220 Göteborg 5, Schweden

1 G. Alberti and S. Allulli, Chromatog. Rev. 10, 99 [1968].

2 V. LJubimov and A. LundÉn, Z. Naturforsch. 21 a, 1592 [1966].

3 A. Lundén and V. LJubimov, Z. Naturforsch. 23a, 1558 [1968].

4 J. Périé, M. Chemla, and M. Gignoux, Bull. Soc. Chim. France 1961, 1249. isotope effects in pure salts. It has been called the column method $^{1}$ since a packed column separates the electrode compartments. After quenching, the whole cell is divided into samples for each of which the amounts present of the different components are determined. In this way it is possible to determine the displacements of one cation species relative to another, and "internal mobilities" can thus be obtained. Since this method is much more tedious than the various open-block ones, it has found little use for salt mixtures except when combined with studies of isotope effects. We have recently reported its use for studying the system $\mathrm{Li}_{2} \mathrm{SO}_{4}-\mathrm{K}_{2} \mathrm{SO}_{4}$ (loc. cit. ${ }^{2,3}$ ). Applications of columns by Chemla and coworkers to isotope enrichment in halide and nitrate mixtures have not been evaluated for cation mobilities ${ }^{4}, 5$. They have, however, reported mobility ratios for an arrangement where a disc separates the two compartments of the cell ${ }^{6,7}$. Our interest for relative mobilities in nitrate melts dates back to our attempts to measure isotope effects for cells containing $\mathrm{LiNO}_{3}$ and $\mathrm{RbNO}_{3}$ (loc. cit. ${ }^{8}$ ). We shall now report on some test measurements of relative mobilities in different binary and ternary mixtures ${ }^{9}$, for which it is possible to make comparisons with mobilities measured by the strip method.

The mixtures studied are listed in Table 1. The length of the separation column was about $20 \mathrm{~cm}$ in all experiments ${ }^{10}$, The concentrations of the alkali metal ions were determined by flame spectrophotometry, of Ca by EDTA titration and of $\mathrm{Ag}$ by thiocyanate titration.

5 F. Lantelme and M. Chemla, J. Chim. Phys. 60, 250 [1963].

6 F. Lantelme and M. Chemla, Bull. Soc. Chim. France $1963,2200$.

7 F. Lantelme and M. Chemla, Electrochim. Acta 10, $663[1965]$.

8 A. Lundén, Ann. N. Y. Acad. Sci. 79, 988 [1960].

9 More extensive investigations are in progress for $\mathrm{KNO}_{3}-\mathrm{RbNO}_{3}$ and $\mathrm{LiNO}_{3}-\mathrm{KNO}_{3}$.

10 For experimental details see e.g. A. Lundén and A. EKHED, Z. Naturforsch. 23a, 1779 [1968]. 
Transport numbers and relative mobilities are calculated by means of the formulas ${ }^{2}$

$$
t_{i}-x_{i}=\left(N_{i}-N_{i}^{0}\right) / Q
$$

and $\quad b_{i k} / b=\left(t_{i} x_{k}-t_{k} x_{i}\right) / x_{i} x_{k}=\left(N_{i} / x_{i}-N_{k} / x_{k}\right) / Q$

where

$b=\underset{\text { ions }}{\Lambda / F}=$ (average) mobility of cations relative to an-

$\Lambda=$ equivalent conductivity

$F=$ Faraday constant

$t_{i}=$ transport number at initial equivalent fraction $x_{i}$

$b_{i k}=$ mobility of species $i$ relative to species $k$

$N_{i}=$ number of equivalents of species $i$ present in a volume for which the original amount was $N_{i}^{0}$

$Q=$ transported charge, Faradays

For all experiments the indices 1, 2, 3 are used in sequence of increasing mass of the cation.

The results are summarized in Table 1 .

\section{Comparison with mobility measurements on strips}

The relation between external mobilities $\left(u_{i}, u_{k}\right)$ and the internal mobility $b_{i k}$ is

$$
b_{i k}=u_{i}-u_{k} .
$$

For calculating relative mobilities from strip experiments we have for pure salts used the conductivity data compiled by JANZ et al. ${ }^{11}$. For mixtures Nooijer's data are used ${ }^{12}$. The mobility $b$ is always calculated for the temperature at which $u$ is reported to be measured. Since there is reason to assume that this temperature is too low for some early investigations ${ }^{13}$, including Arnikar's, this means that the calculated relative mobilities are too high in these cases.
Li, Ca-nitrate: KWAK ${ }^{14}$ has measured the mobilities of $\mathrm{Li}$ and $\mathrm{Ca}$ on a strip containing a $\mathrm{LiNO}_{3}-\mathrm{Ca}\left(\mathrm{NO}_{3}\right)_{2} \mathrm{mix}$ ture. From his results for 80 equv. $-\% \mathrm{LiNO}_{3}$ at $304^{\circ} \mathrm{C}$ it follows that $u_{\mathrm{Li}}-u_{\mathrm{Ca}}=2.08 \times 10^{-4} \mathrm{~cm}^{2} V^{-1} \mathrm{~s}^{-1}$, which corresponds to $b_{12} / b=0.67$ (l. c. ${ }^{15}$ ) which is in good agreement with our results, and also with measurements of $u_{\mathrm{Li}}$ and $u_{\mathrm{Ca}}$ in other metls, e.g. pure $\mathrm{NaNO}_{3}$ at $350^{\circ} \mathrm{C}$ (ARNI$\left.\mathrm{KAR}^{16}\right): u_{\mathrm{Li}}-u_{\mathrm{Ca}}=2.87 \times 10^{-4} \mathrm{~cm}^{2} V^{-1} \mathrm{~s}^{-1}$, and equimolar $\mathrm{NaK}\left(\mathrm{NO}_{3}\right)_{2}$ at $270^{\circ} \mathrm{C}$ (BERLIN et al. $\left.{ }^{17}\right) u_{\mathrm{Li}}-u_{\mathrm{Ca}}$ $=1.58 \times 10^{-4} \mathrm{~cm}^{2} \mathrm{~V}^{-1} \mathrm{~s}^{-1}$.

$\mathrm{Na}, \mathrm{K}$-nitrate: HoN $\mathrm{IG}^{18}$ has measured mobilities of $\mathrm{Na}$ and $\mathrm{K}$ in mixtures of $\mathrm{NaNO}_{3}$ and $\mathrm{KNO}_{3}$. For $90 \% \mathrm{NaNO}_{3}$ his data gives $u_{\mathrm{Na}}-u_{\mathrm{K}}=0.43 \times 10^{-4} \mathrm{~cm}^{2} \mathrm{~V}^{-1} \mathrm{~s}^{-1}$ at $350^{\circ} \mathrm{C}$. For pure $\mathrm{NaNO}_{3}$ at $350^{\circ} \mathrm{C} u_{\mathrm{Na}}-u_{\mathrm{K}}$ is obtained as $0.64 \times 10^{-4} \mathrm{~cm}^{2} \mathrm{~V}^{-1} \mathrm{~s}^{-1}\left(\right.$ ARNIKAR ${ }^{16}$ ) or $0.30 \times 10^{-4} \mathrm{~cm}^{2} \mathrm{~V}^{-1}$ pro s (Hon IG ${ }^{18}$ ). Mobility differences of the same order of magnitude are reported for the equimolar $\mathrm{NaNO}_{3}-\mathrm{KNO}_{3}$ mixture. It was found that the mobility difference decreases with increasing temperature. The strip measurements are thus in disagreement with our result.

$N a, K, R b$-nitrate: The studied ternary mixtures can be considered as dilute solutions of $\mathrm{NaNO}_{3}$ and $\mathrm{RbNO}_{3}$ in $\mathrm{KNO}_{3}$. For this reason only $b_{12} / b$ and $b_{23} / b$ will be considered in our comparison. Regarding $b_{12} / b$ we are in a concentration and temperature region where there is disagreement in the literature whether $b_{\mathrm{Na}}$ is larger or smaller than $b_{\mathrm{K}}$. Thus at $350^{\circ} \mathrm{C}$ HoniG's 18,19 values of $u_{\mathrm{Na}}$ and $u_{\mathrm{K}}$ for a mixture of $10 \% \mathrm{NaNO}_{3}$ and $90 \% \mathrm{KNO}_{3}$ coincide within experimental error, while he finds that $u_{\mathrm{Na}}-u_{\mathrm{K}}=-0.12 \times 10^{-4}$ $\mathrm{cm}^{2} \mathrm{~V}^{-1} \mathrm{~s}^{-1}$ for pure $\mathrm{KNO}_{3}$. On the other hand, ARNIKaR 16 reports this difference to be $1.88 \times 10^{-4} \mathrm{~cm}^{2} \mathrm{~V}^{-1} \mathrm{~s}^{-1}$. The relative mobilities of $\mathrm{Na}^{+}$and $\mathrm{K}^{+}$have also been studied with the disc method by Lantamele and Chemla ${ }^{6}$, who find i. a. that $u_{\mathrm{Na}}>u_{\mathrm{K}}$ for all concentrations at $360^{\circ} \mathrm{C}$, but that $u_{\mathrm{Na}}<u_{\mathrm{K}}$ at $400^{\circ} \mathrm{C}$ for mixtures containing more than

\begin{tabular}{|c|c|c|c|c|c|c|c|c|c|c|c|c|}
\hline \multirow[t]{2}{*}{$\begin{array}{c}\text { Exp. } \\
\text { no }\end{array}$} & \multirow[t]{2}{*}{ Cations $^{\text {a }}$} & \multirow[t]{2}{*}{$\begin{array}{l}100 \cdot x_{1} \\
\text { eq. } \%\end{array}$} & \multirow[t]{2}{*}{$\begin{array}{l}100 \cdot x_{3} \\
\text { eq. } \%\end{array}$} & \multirow{2}{*}{$\underset{{ }^{\circ} \mathrm{C}}{\text { Temp. }}$} & \multirow{2}{*}{$\begin{array}{l}\text { Dura- } \\
\text { tion } \\
\text { hours }\end{array}$} & \multirow{2}{*}{$\begin{array}{l}\text { Trans. } \\
\text { port } \\
\text { charge } \\
\text { mFara- } \\
\text { day }\end{array}$} & \multicolumn{2}{|c|}{$\begin{array}{l}\text { Transport } \\
\text { numbers }\end{array}$} & \multicolumn{2}{|c|}{$\begin{array}{l}\text { Mobilities; } \\
\text { Our results }\end{array}$} & \multicolumn{2}{|l|}{$\begin{array}{l}\text { Mobilities; } \\
\text { strip experiments }\end{array}$} \\
\hline & & & & & & & $t_{1}$ & $t_{3}$ & $b_{12} / b$ & $b_{23} / b$ & $b_{12} / b$ & $b_{23} / b$ \\
\hline 1 & $\mathrm{Li}, \mathrm{Ca}$ & 80.4 & - & 300 & 21.5 & 211.7 & 0.814 & - & 0.62 & - & $0.67^{14} ;\left(0.52^{16} ; 0.39^{17}\right)$ & - \\
\hline 2 & $\mathrm{Na}, \mathrm{K}$ & 91.8 & - & 376 & 12 & 136.0 & 0.963 & - & 0.59 & - & $0.08^{18} ;\left(0.12^{16} ; 0.06^{18}\right)$ & - \\
\hline 3 & $\mathrm{Na}, \mathrm{K}, \mathrm{Rb}$ & 5.3 & 4.4 & 381 & 37.2 & 249.4 & 0.054 & 0.041 & 0.021 & $0.069 \mid$ & $000618 \cdot(-0,03218 \cdot 04916)$ & \\
\hline 4 & $\mathrm{Na}, \mathrm{K}, \mathrm{Rb}$ & 6.5 & 5.4 & 380 & 30.6 & 229.3 & 0.067 & 0.051 & 0.029 & $0.056\}$ & $0.006^{18} ;\left(-0.032^{18} ; 0.49^{16}\right)$ & $0.031^{18}$ \\
\hline 5 & $\mathrm{Li}, \mathrm{K}, \mathrm{Ag}$ & 90.5 & 5.2 & 291 & 7.0 & 60.6 & 0.907 & b & 0.15 & b & & \\
\hline
\end{tabular}
$60 \% \mathrm{KNO}_{3}$.

Table 1. Data of electromigration experiments.

a The sequence of the ions corresponds to that of the indexes.

b Interpretation difficult due to partial decomposition of $\mathrm{AgNO}_{3}$.

11 G. J. JANZ et al.: Molten Salts: Vol. 1, Electrical Conductance, Density, and Viscosity Data, NSRDS-NBS 15, Nat. Bur. Stand., Washington 1968.

12 B. DE NoolJer, Thesis Amsterdam 1965.

13 E. P. Honig and J. A. A. KetelaAR, Trans. Faraday Soc. 62, 190 [1966].

14 J. C. T. Kwak, Thesis Amsterdam 1967.
15 For the rest of this comparison the relative mobilities will be given only in Table 1 , where they are given in the same order as the underlying external mobility measurements are mentioned in the text.

16 H. J. Arnikar, Ann. Phys. Paris (13) 4, 1291 [1959].

17 A. Berlin, F. Ménès, S. Forcheri, and C. Monfrini, J. Phys. Chem. 67, 2505 [1963].

18 E. P. Honig, Thesis Amsterdam 1964.

19 Honig's results regarding $u_{\mathrm{Na}}$ in $\mathrm{KNO}_{3}$ have been confirmed by KwaK ${ }^{13,14}$. 
Turning our attention to the heavy impurity $\mathrm{RbNO}_{3}$, mobility data exist for a strip with $\mathrm{KNO}_{3}$ at $450^{\circ} \mathrm{C}$ from which it follows that $u_{\mathrm{K}}-u_{\mathrm{Rb}}=0.14 \times 10^{-4} \mathrm{~cm}^{2} \mathrm{~V}^{-1} \mathrm{~s}^{-1}$, which is in reasonable agreement with our results.

$L i, K, A g$-nitrate: Due to thermal decomposition our samples from the separation column were found to contain both $\mathrm{AgNO}_{3}$ and silver as metal or oxide. Of course this complicates calculations of $b_{13} / b$ but is not so important for $b_{12} / b$.

Regarding $b_{13} / b$, our experiments only allow the qualitative conclusion that it is likely that $b_{\mathrm{Ag}}>b_{\mathrm{Li}}$ in our $\mathrm{LiNO}_{3}$ rich mixture. As for $b_{12} / b$, it is difficult to make any meaningful comparisons, since data on external mobilities in pure $\mathrm{LiNO}_{3}$ or $\mathrm{LiNO}_{3}$-rich mixtures are very scarce, and the values of $u_{\mathrm{Li}}$ and $u_{\mathrm{K}}$ determined in other melts spread considerably.

\section{Discussion}

Some possible sources of experimental error should be remembered. As pointed out previously ${ }^{1}$, there are differences in the way the different authors have evaluated their measurements of external mobilities. Also, $u_{1}-u_{2}$ is not measured directly but calculated from more or less independent measurements of $u_{1}$ and $u_{2}$. Regarding our experiments with columns, in principle, two types of disturbances can occur at solidification. Thus, a certain remixing might result from flow caused by volume changes. In this case the measured value of $b_{12} / b$ would tend to become too small, while, on the other hand, partial fractionation during solidification would give rise to $b_{12} / b$ values which are too high. The importance of these two sources of error depends on the construction of the cell as well as on the quenching technique.

Consequently, either method of determining $b_{i j}\left(\right.$ or $\left.b_{i j} / b\right)$ has its weaknesses, and the results obtained so far should be viewed with some suspicion. Bearing this in mind, it is comforting that the different measurements agree reasonably well for $\mathrm{Li}-\mathrm{Ca}$ and $\mathrm{K}-\mathrm{Rb}$, while the serious discrepancies for $\mathrm{Na}-\mathrm{K}$ are a challenge for further work.

\section{Acknowledgements}

This investigation is supported by "Statens Naturvetenskapliga Forskningsråd". I am indebted to Mrs. A. EkLund, Mrs. L. JANSEN and Mr. B. VIDHög for performing the chemical analyses. 